\title{
Ovarian Mucinous Adenofibroma
}

National Cancer Institute

\section{Source}

National Cancer Institute. Ovarian Mucinous Adenofibroma. NCI Thesaurus. Code C40040.

A benign neoplasm of the ovary characterized by the presence of glands with mucinous columnar epithelial cells in a fibrotic stroma. 